\title{
Discoveries in Pharmacological Sciences
}


This page intentionally left blank 


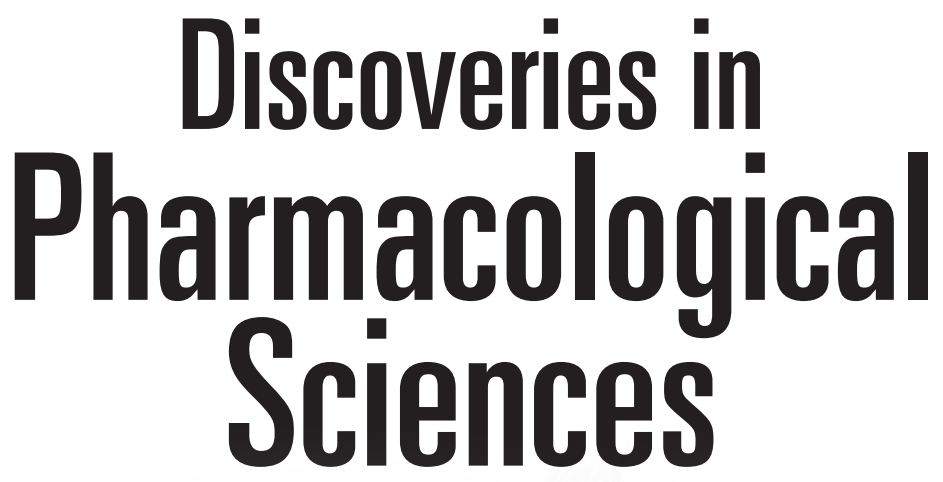

\section{Popat N. Patil}

The Ohio State University, USA 


\section{Published by}

World Scientific Publishing Co. Pte. Ltd.

5 Toh Tuck Link, Singapore 596224

USA office: 27 Warren Street, Suite 401-402, Hackensack, NJ 07601

UK office: 57 Shelton Street, Covent Garden, London WC2H 9HE

\section{Library of Congress Cataloging-in-Publication Data \\ Patil, Popat N., 1934- \\ Discoveries in pharmacological sciences / Popat N. Patil. \\ p. ; cm. \\ Includes bibliographical references and index. \\ ISBN-13: 978-9814355070 (hardcover : alk. paper) \\ ISBN-10: 9814355070 (hardcover : alk. paper)}

I. Title.

[DNLM: 1. Drug Discovery--history. 2. Pharmacology--history. QV 711.1]

$615.1--\mathrm{dc} 23$

2011045494

\section{British Library Cataloguing-in-Publication Data}

A catalogue record for this book is available from the British Library.

Copyright (c) 2012 by World Scientific Publishing Co. Pte. Ltd.

All rights reserved. This book, or parts thereof, may not be reproduced in any form or by any means, electronic or mechanical, including photocopying, recording or any information storage and retrieval system now known or to be invented, without written permission from the Publisher.

For photocopying of material in this volume, please pay a copying fee through the Copyright Clearance Center, Inc., 222 Rosewood Drive, Danvers, MA 01923, USA. In this case permission to photocopy is not required from the publisher.

Typeset by Stallion Press

Email: enquiries@stallionpress.com

Printed in Singapore. 


\title{
Dedication
}

\author{
To my Grandchildren: \\ Mikah, Allie, Jack, George, Grace, Alec, Josephine, Conner, \\ Mason and the younger generation of Bedse-Patils, \\ Chinchkhede, M.S., India.
}


This page intentionally left blank 


\section{Contents}

Acknowledgements - ix

Preface xi

$\begin{array}{lll}\text { Part } 1 \text { Drug Discoveries } & 1\end{array}$

Chapter 1 Evolution, Human Migration, Diseases and Treatments

Chapter 2 Ancient Medicine and the Discovery of Natural Therapeutic Agents

Chapter 3 History of Anesthesia, Acupuncture, Hypnosis, Mesmerism, Anesthetics and Hypnotics 181

Chapter 4 Emergence of Modern Medicine 205

Chapter 5 Contributions of Anatomists and Physiologists to the Neurofunctional Outline of the Nervous System

Part 2 20th Century Drug Discoveries Research, Pharamacology Education, Laws and Pharamaceutical Companies

Chapter 6 Pharmacology Comes of Age

Chapter 7 Discovery of Receptors and Related Events: A Century of Receptors and Transduction

Chapter 8 Development of Drug Laws and Quantitation 
Chapter 9 Drug Discoveries

Chapter 10 Growth of the Drug Industry, Research Institutions and Universities

Index 


\section{Acknowledgements}

Since 2005, the efficient staff of The Ohio State University have provided the most valuable assistance in transcribing my teaching notes, PowerPoint and handwritten report for the document. I'd like to thank Elizabeth Bulgrin (major responsibility) and Sharon Palko for their transcription skills, Casey Hoerig for computer assistance, Susan M. Lutz for searching for many images, as well as Bruce Leach, Natalie Kupferberg and Ann T. Gillialand for the additional help in the search. Ben Naman and Ye Deng formatted all the chemical structures; David Keegan of the Albert and Mary Lasker Foundation, Mary Holtz of Matas Medical Library of Tulane University; Rachael Johnson of Wellcome Library; Nicole L. Babcock, Historical Archives Specialist at Mayo Clinic; Douglas Atkins of the National Library of Medicine; Patrick L. Sim of the Wood Library-Museum of Anesthesiology; Michael Frings of Bayer Business Services for corporate history and archives; and Donald Tobias of Pfizer was thoughtful in donating valuable images. Information from guest seminars, discussions and personal communication with Robert R. Ruffolo, Jr.; Duane Miller; Dennis Feller; John Fowble; Chenglong Li; Harold Wolf; Ted Sokoloski; Richard J. Seidehamel; Richard Hill; Louis DeSantis; Margarita Salazar-Bookaman; Ted Sokoloski; B.D. Garg; Peter J. Rice; Lesley Lluka; Albert Soloway; Manuel Tzagournis; John Daly; Mark Bahar; Mark Strauch; Urs Meyer; Louis Ignarro; Robert Lefkowitz; David Jacobowitz; Raphael Mechoulam; Koji Nakanishi; Alberto Kaumann; B. Waldeck; George Pettit; Solomon Snyder, Randy Nelson and Elaine Fuchs have been included in the text. Vandana Kumari and Li modeled the adreno-receptor reactive molecules. Beth Balog for 
discussing PharmD class presentation on sleep aid medications. I would like to express my gratitude to Raymond Doskotch for providing several critical references and A. Douglas Kinghorn and Mansukh Wani for stimulating scholarly discussions; Joseph Gal for providing reprints on the history of stereochemical terminology and the research of Louis Pasteur; Harkishan Singh for the reprints on Colonel R. N. Chopra; Crystal Patil for updating the status of sickle cell anemia; Nicholas Petropoulos provided valuable information on Alexander the Great; lan Hughes for providing the input on pharmacology curriculum with the question - How do we know they (students) learn? Richard Hill and Allan Burkman for writing the textbook on Ocular Pharmacology and Toxicology; Gopi Tejwani and Michael Gerald for their interest in the history of pharmacology; Mark Gerhardt for his lecture outline on anesthesia; Carl Buckner for donating teaching notes; and David George for the reference on toxicology. Hitoshi Ishikawa provided useful documents on Shibasaburo Kitasato, and Satoshi Ishikawa kindly updated on the toxicity of pesticides. Amitava Sanyal for reviewing the toxicity of heavy metals in food chain. I recognize Glenn Sonnedecker, Jack L. Beal, Milap Nahata, John Parascandola, Elaine Stroud, Kari Hoyt, Robert Buerki, Lynn Eltner, Anish Konkar, Z. H. Song, Karl Werbovetz, James Fuchs, Larry Robertson, Dennis McKay, Jack Yalowich, Tony Young, Ryan Schneider, Vivek Garg, Prashant Nikam, Veronique Lacombe, O.D. Gulati, R. Balaraman, R.K. Goyal, Sanjay Surana, Sunil Bothara and Lane Wallace for their general interest in teaching of drug discovery. Colleagues providing editing input on some chapters include: John Burnham, Judith Weiner, John E. Sauer, George Paulson, A. Douglas Kinghorn, Robert Curley, Edward Behrman, Jack Rall, Emily Keeler and Keli Hu. Proofreading assistance from Tatiana Gonzalez-Cestari, Bitna Yi, Brandon Henderson, Anita Patil and many hours of time of Betsy Bulgrin and Betty Patil including her gift of history book is appreciated. Special acknowledgement goes to Milicia Patil for her graphic design skills, and to Sook-Cheng Lim and the team of World Scientific for the efficient help in formatting-editorial activities. 


\section{Preface}

Human diseases existed long before the discoveries of drugs. With human migration from Africa nearly 150,000 years ago, human curiosity, intellect and creativity began to flourish — as did disease and treatment. The first recorded use of medicine appears 5,000 years ago when the multicultural societies of Mesopotamia introduced herbal medicine and the code of Hammurabi into medical practice. Later, lists of prescriptions appeared on Egyptian Papyrus, in Indian Ayurvedic medicine, in Chinese herbal documents, and in GrecoRoman Dioscorides' Materia Medica. Discovery is a cumulative process. The information in ancient society, however, was scattered. In many cases, the utility of medicines was understood, but the logistics of sharing discoveries proved difficult. Developments in treatments progressed slowly. In $160 \mathrm{AD}$, based on his observation of functional anatomy of laboratory animals, Galen promoted medical treatments that lasted over a thousand years. Galen's dogma was not challenged until the beautiful and anatomically accurate drawings of Andreas Vesalius were published in 1543. The discovery of circulation by William Harvey was reported in 1628 AD and provided a better foundation for the medical practice of the day. After $1700 \mathrm{AD}$, starting with hospital bedside observations of patients by Herman Boerhaave, physicians discovered many pathologies: Bright's disease, Grave's disease, Addison's disease, Angina, Glaucoma, Parkinson's disease, Asthma, Cancer, Alzheimer disease, Schizophrenia and other Neurological diseases. Thus, diseases known through ancient times are still current challenges. The Nobel achievements of James Watson, Francis Crick, Francis Collins, J. Craig Venter and Elizabeth Blackburn created new refined molecular targets for the drug discovery. 
It is important to note that plants containing morphine, quinine, physostigmine, pilocarpine, (-)-hyoscyamine, (+)-tubocurarine, reserpine, tetrahydrocannabinol, cardiac glycosides, ephedrine and colchicine were used by various cultures for centuries. In 1805 AD, the German pharmacist, Friedrich Sertürner isolated pure morphine (Morpheus) from poppy capsules. French pharmacists, P.J. Pelletier and J.B. Caventau in 1820 AD isolated quinine and other alkaloids. For the study of drug action, the Parisian pharmacists collaborated with Francois Magendie, a famous physiologist who correctly discovered dorsal (sensory) and ventral (motor) nerves of the spinal cord. Thus, Magendie is considered the founder of modern experimental pharmacology. Parallel to these developments, Charles Darwin, Gregore Mendel and Louis Pasteur added spectacular discoveries in evolution, laws of heredity and biologic specificity of $(+)$ and (-)-tartrates. Anesthetic properties of ether were discovered.

The growth in drug discovery continued to be aided by advances in other sciences. The U.S. army physician, Fredrick Beamont first published the nature of gastric digestion by observing a patient with a bullet wound to the stomach. A pupil of Michael Foster, Charles Sherrington coined the term synapse and recognized the reciprocal (activation and active inhibition) control of the skeletal muscle. John $\mathrm{N}$. Langley not only outlined the nervous system but used nicotine and curare alkaloids to postulate the pharmacologic receptors at the neuroeffector junction. The chemical structures of natural products were elucidated. Based on the template of alkaloidal structures, hundreds of synthetic analogues were prepared and tested to improve the therapeutic index. J.H. Gaddum, H.O. Schild and E.J. Ariens introduced better methods to quantitate drug receptor interactions. R.P. Stephenson recognized functional receptor reserve for the potent agonists in organs. Hormones and neurotransmitters were characterized. After the 1820s, Merck, Wyeth, Lilly, Merrell, Abbott, and Upjohn pharmaceutical companies had their specialty products marketed through the innovative research. The era of antibiotics, sulfa drugs, vitamins and psychotropic medication emerged and soon the distinction between basic academic and applied research disappeared. 
An understanding of the history of drugs and toxic chemicals is essential for the proper utility of these substances. It is also an invaluable aid to future innovation. Thus the educational need became eminent. This book provides a critical analysis of the major discoveries in pharmacology, including time, places and scientists involved. The title Discoveries in Pharmacological Sciences includes biochemical, morphological aspects of neuroscience, pharmaceutical, physiological, and toxicological sciences. The book contains the following topics: Evolution, human migration, diseases and treatments; ancient medicine and the discovery of natural therapeutic agents; history of anesthesia, acupuncture, hypnosis, mesmerism, anesthetics and hypnotics; emergence of modern medicine; contributions of anatomists and physiologists to the neurofunctional outline of the nervous system; pharmacology comes of age; discovery of receptors and related events, a century of receptors and transduction; development of drug laws and quantitation; drug discoveries; and growth of the drug industry, research institutions and universities. There is some overlap in chapter topics. Summaries for each chapter are added. The book is written for graduate students, scientists and faculty with the purpose to familiarize the investigators about the discoveries in chemical, pharmaceutical, pharmacological, clinical and biomedical sciences. Brief profiles of scientists are included. Their discoveries are fascinating.

I had fun in finding connecting stories of drug discoveries through the ages; it has been a rewarding research, teaching and writing experience. During my academic career, either on the campus or at other locations, I was fortunate to get exceptional help and meet many distinguished scientists interested in pharmacological sciences, namely: Chauncey D. Leake, Arther Tye, Emil Bozler, Eric Ogden, Robert Gardier, Melvin Newman, Prabir Dutta, K.K. Chen, Irvine Slater, E.J. Ariens, J.M. Van Rossum, A.M. Simonis, Richard Shultes, Robert Furchgott, Ullrich Trendelenburg, William Fleming, Solomon Langer, Norman Weiner, Michael Rand, Robert Maxwell, David Triggle, Philip Portoghese, Jules LaPidus, Ulf S. von Euler, L. Terenius, Eric Muscholl, Hermann Blaschko, Julius Axelrod, Solomon Snyder, Robert Lefkowitz, A.G. Gilman, Jr., J.C. Venter, Edith Bülbring, Marthe Vogt, B.N. Dhawan, 
Raphael Mechoulam, Sir James Black, Heinz O. Schild, Hans Thoenen, Arvid Carlsson, E. De Robertis, Har Govind Khorana, Jean-Pierre Changeux, George Koelle, John P. Long, Elmer Szabadi, Satoshi Ishikawa, Arnold Schwartz, W.F. Ganong, John Bevan, and O.D. Gulati. I am enriched by their scientific and academic contributions, as I hope the reader will be by this book. Accordingly I would quote Will Durant, "Happiness dies when it is not shared."

Popat N. Patil August 15, 2011 